\section{Notes on the reproductive biology of Heterometrus phipsoni Pocock, 1893 (Scorpiones: Scorpionidae)}

\author{
Zeeshan A. Mirza ${ }^{1}$ \& Rajesh Sanap ${ }^{2}$ \\ 11-13 Shiv Colony, Marol Police Camp, Andheri (east), Mumbai, \\ Maharashtra 400059, India \\ ${ }^{2}$ D-5/ 2, Marol Police Camp, M.M. Road, Andheri (east), Mumbai, \\ Maharashtra 400059, India \\ Email: ${ }^{1}$ snakeszeeshan@gmail.com; ${ }^{2}$ rajeshvsapan@gmail.com
}

The genus Heterometrus Ehrenberg, 1828 is represented in India by at least 20 species (Kovarík 2004). Heterometrus phipsoni Pocock, 1893 was originally described as Scorpio phipsoni Pocock, 1893 from Shevroy Hills, Tamil Nadu. Tikader \& Bastawade (1983) included Raighad, Thane, Rannagiri, Nasik and Kolhapur districts, Maharashtra in the distribution. Kovarík (2004) subsequently, reported the species from Kerala, Madhya Pradesh, West Bengal and Orissa”.

Despite wide distribution Heterometrus species in India have received very little attention on reproductive biology and ecological studies have been documented for H. scaber Thorell (Mathew 1957) H. longimanus Herbst (Polis \& Sissom 1990) and Heterometrus fulvipes Brunner (Shivasankar 1994).

Observation made on the reproductive biology of Heterometrus phipsoni under laboratory conditions and post insemination spermatophore conditions with some notes on the natural history is documented here.

\section{Material and Methods}

Two males and a single female specimen $H$. phipsoni were collected from Aarey Milk Colony while documenting the scorpion fauna of northern Western Ghats and housed in a plastic container with loose soil as the substrate. The scorpions were fed on cultured beetle larvae (Mirza et al. 2009) and on

Date of publication (online): 26 September 2009

Date of publication (print): 26 September 2009

ISSN $0974-7907$ (online) | $0974-7893$ (print)

Editor: Vinod Khanna

\section{Manuscript details:}

Ms \# 02234

Received 09 June 2009

Final received 31 August 2009

Finally accepted 03 September 2009

Citation: Mirza, Z.A. \& R. Sanap (2009). Notes on the reproductive biology of Heterometrus phipsoni Pocock, 1893 (Scorpiones: Scorpionidae). Journal of Threatened Taxa 1(9): 488-490.

Copyright: (C) Zeeshan A. Mirza \& Rajesh Sanap 2009. Creative Commons Attribution 3.0 Unported License. JoTT allows unrestricted use of this article in any medium for non-profit purposes, reproduction and distribution by providing adequate credit to the authors and the source of publication.

Acknowledgment: We thank Amod Zambre and R. Sreekar for literature. Special thanks to Rishikant Jha for help in collecting morphometric data and assistance in the field. We acknowledge all who assisted in the field and provided financial support. Special thanks to Jan O. Rein improving the manuscript. We are thankful to the Vincent Roth Fund for Systematics Research of the American Arachnological Society for a generous grant to support field work in the northern Western Ghats. Special thanks to Agarwal Charitable Trust for logistic support.

OPEN AGCESS | FREE DOWNLOAD

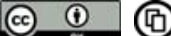

certain occasions, geckos of the genus Hemidactylus too. Terminology adopted in the description of the spermatophore is after Francke (1979) and that for reproductive behavior follows Polis and Sissom (1990).

\section{Result}

On 13 April 2008 at $1625 \mathrm{hr}$, a male Heterometrus phipsoni was introduced in a plastic box in which the female (H. phipsoni) was housed. The female was in a corner of the box and the male approached the female and stopped as the pedipalp of both the male and female were in contact. The male started pushing the female away to the middle. Though this took time as the smaller male took time it succeeded in grabbing the female's pedipalp and initiated the promenade (Image 1). The mating dance 'promenade à deux' continued with cheliceral massage (Image 2). During this activity the female stung the male. The cheliceral and pedipalp massage is performed by the male to make the female docile, cooperative or simply to suppress the aggression of the female (Polis \& Sissom 1990). The male guided the female to a corner where the substrate (loose soil) was moved and the base cleared. The pair remained there for five minutes. At $1658 \mathrm{hr}$ the male left the female and a minute later the female violently stung the male and drove it out of the box. A few drops of water sprinkled on the chelicerae of female were accepted. The female moved forward and arched the mesosoma touching the base of the box, possibly for sperm uptake (Image 3). Throughout the promenade, the male was observed rapidly moving the pectenes and juddering of the body was observed.

On 24 June 2008 the female was observed with nine juveniles on her back (Image 4), which were bright white in color with tinge of yellowish-brown measuring 10 to $15 \mathrm{~mm}$ (Image 5). During the gestation period, the female did not accept any food in the first month but accepted four mealworms and a juvenile Hemidactylus cf. brookii. The gestation period recorded is two months and 11 days i.e. 71 days. After mating, there was no trace of spermatophore, probably consumed by either. Out of the nine juveniles, one was deformed due to the absence of metasoma (Image 6). The juveniles abandoned the female after four moults. The juveniles were retained for further observations and were released as they got dark colouration.

On 2 July 2008 at 1430 hr, another male $H$. phipsoni was introduced in the box along with the female. The female mated again and the post insemination spermatophore (Image 7) was collected and preserved in 3\% formaldehyde. Comparison of the courtship behavior of Heterometrus phipsoni and Heterometrus scaber is summarized in Table 1. Four days after mating the female was found dead in the box.

Spermatophore: The spermatophore was found on the base of the plastic box among leaf litter, not attached to base. The lamina being flexible appears straight (Image 7). Spermatophore lamelliform (Fig. 1). Pedicel $0.46 \mathrm{~mm}$ long, $0.60 \mathrm{~mm}$ wide. Pedal flexure distinct. Trunk $5.67 \mathrm{~mm}$ long, semicircular in cross-section. Truncal flexure marked ventrally by fair infolding, laterally by paired symmetrical inflections, and dorsally by broad median lobe projecting distally over sperm duct opening. Capsule simple, consisting of symmetrically folded invagination. Lamina $4.70 \mathrm{~mm}$ long appears rather flexible terminally. 


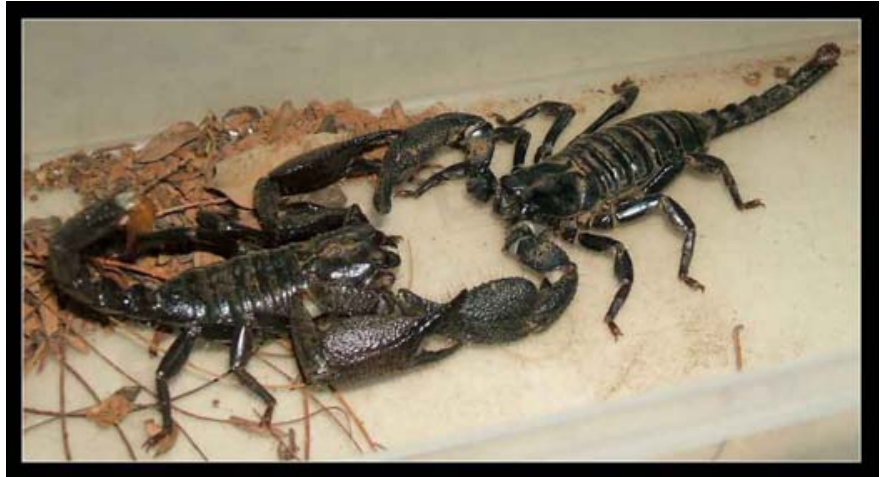

Image 1. Male \& female $H$. phipsoni engaged in mating dance 'promenade à deux'.

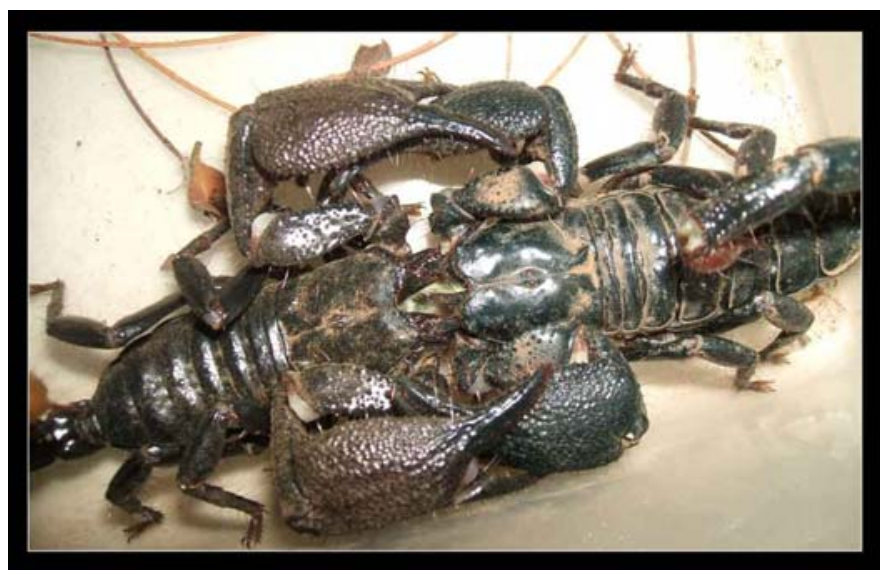

Image 2. Male $H$. phipsoni massaging the female's chelicerae to make her more cooperative and less aggressive.

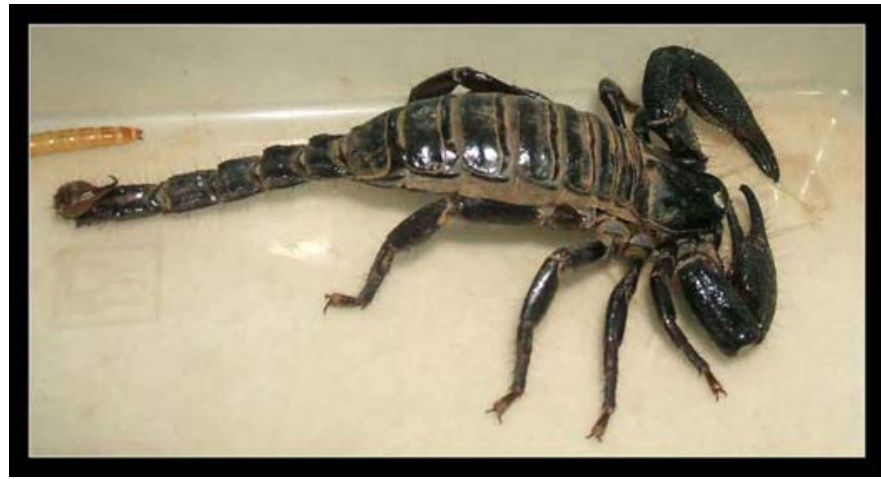

Image 3. Female $H$. phipsoni with its mesosoma arched, an act performed for sperm uptake.

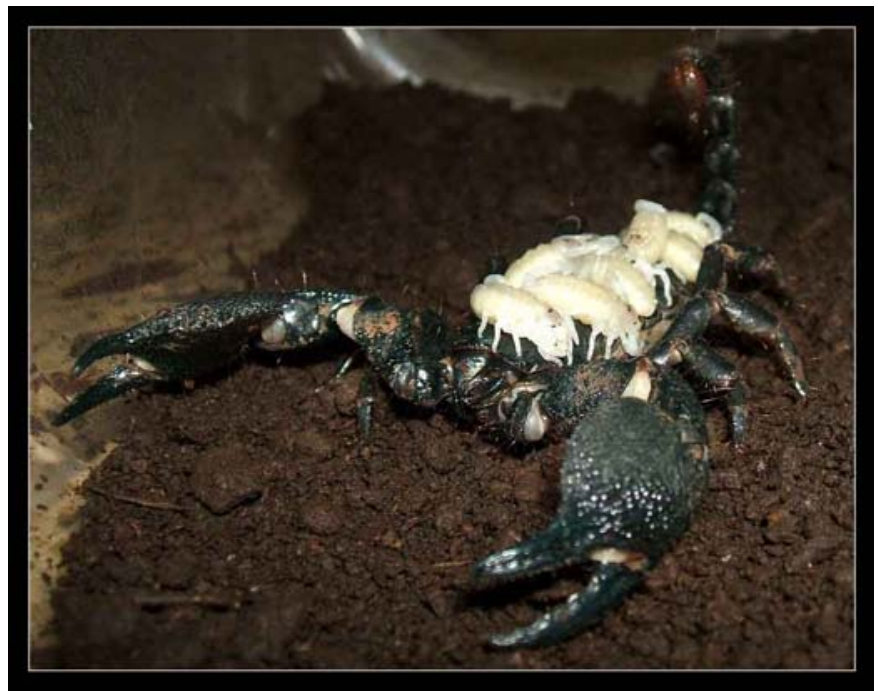

Image 4. Female $\boldsymbol{H}$. phipsoni with juveniles.

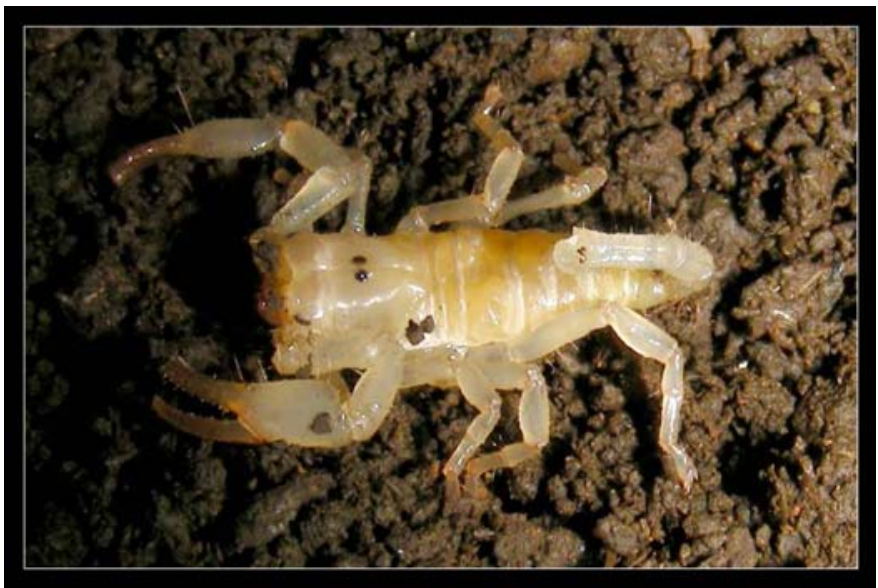

Image 5. A juvenile.

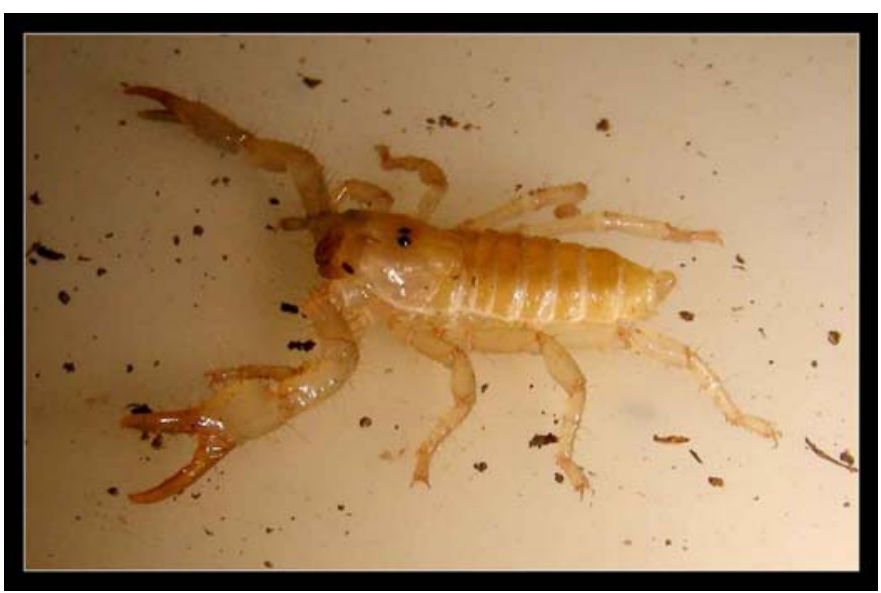

Image 6. A deformed juvenile without the metasoma. 


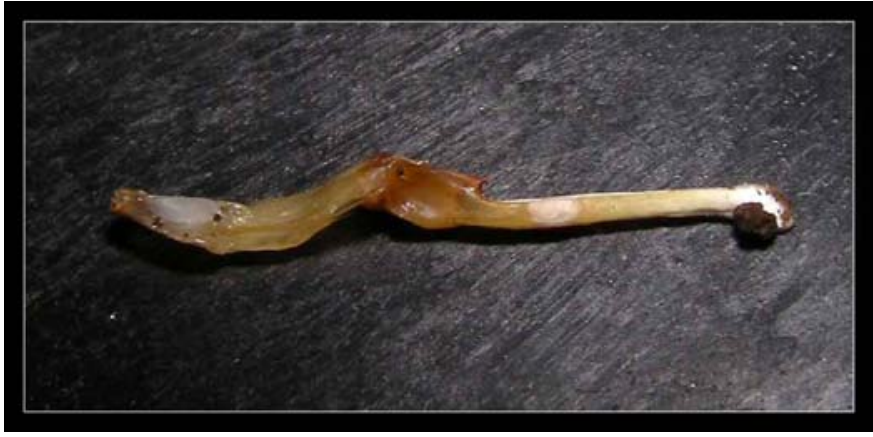

Image 7. Postinsemination spermatophore of $H$. phipsoni.

Table 1. Courtship and mating behavior of Heterometrus phipsoni and Heterometrus scaber

\begin{tabular}{lll}
\hline Parameters & $\begin{array}{l}\text { H. phipsoni } \\
\text { (This work) }\end{array}$ & $\begin{array}{l}\text { H. scaber } \\
\text { (Polis, 1990:83) }\end{array}$ \\
\hline Initiation & Male & Male \\
Male juddering & + & - \\
Male pectinmovement & + & + \\
Clubbing & + & - \\
Pedipalp grip & + & + \\
Chelicera grip & + & - \\
Sexual sting & + & + \\
Chelicera massage & + & - \\
Pedipalp Massage & + & - \\
Male sand scraping & + & + \\
Female head stand & + & Male \\
Post mating escape & Male & \\
\hline
\end{tabular}

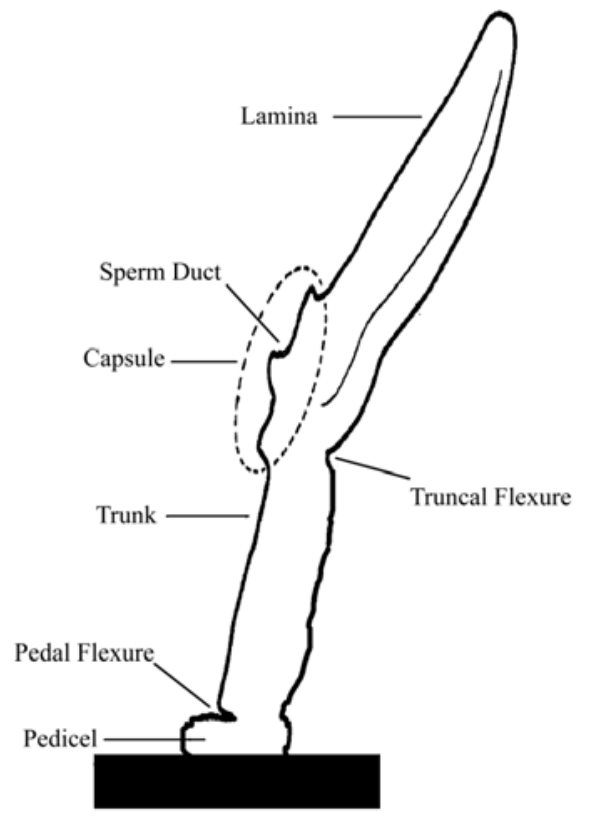

Figure 1. Diagrammatic representation of the spermatophore of $H$. phipsoni.

\section{Conclusion and Discussion:}

The reproductive behavior of $H$. phipsoni is similar to that of $H$. scaber and several other scorpions. The only behavior which has not been reported is the pedipalp massage. Polis \& Sissom (1990) have summarized the behavioral patterns exhibited by scorpions but do not mention pedipalp massage by male. The pedipalp massage happened after the female stung the male and was performed by the male. The present study reports gestation period of 71 days for a litter size of nine juveniles and parturition observed in the month of June, while $H$. longimanus is reported to give birth to 34 juveniles with a gestation period of 12 months and parturition in the month of July and H. scaber litter size to be 30-35 (Polis \& Sissom 1990).

H. phipsoni is a common scorpion occurring in the Sanjay Gandhi National Park, Film City and Aarey Milk Colony in Mumbai occupying burrows and taking refuge under large boulders firmly embedded in the ground with other sympatric species namely Lychas sp. and Hottentotta tumulus. Most of the scorpions were found to occupy burrows at the base of trees. An individual was observed feeding on moths which were attracted to the headlights of a vehicle on the road just after heavy rains. A male and female were observed engaged in promenade in a tunnel in the Sanjay Gandhi National Park in the month of February. Further studies are required to determine the gestation period, and relationship with litter size of scorpions in India.

\section{References}

Francke, O.F. (1979). Spermatophores of some North American Scorpions (Arachnida, Scorpiones). Journal of Arachnology 7:19-32.

Gour-Broome, V. \& A. Zambre (2007). Sting in the tail, scorpion vignettes from Maharashtra. Sanctuary Asia XXVII (1): 60-65.

Kovarík, F. (2004). A Review of the genus Heterometrus Ehrenberg, 1828 , with descriptions of seven new species (Scorpiones, Scorpionidae). Euscorpius - Occasional Publications in Scorpiology No. 15: $1-60$.

Mathew, A.P. (1957). Mating in scorpions. Journla of the Bombay Natural History Society 54: 853-857.

Mirza, Z., K. Ullalkar \& G. Desouza (2009). Notes on the breeding of Hottentotta pachyurus Pocock, 1897 (Scorpiones: Buthidae). Journal of Threatened Taxa 1(3): 186-187.

Polis, G. \& W.D. Sissom (1990). Life History, pp. 81-111. In: Polis, G. (eds.) Biology of Scorpions. Stanford, CA: Stanford University Press, $233 \mathrm{pp}$.

Shivashankar, S. (1994). Advanced sub social behavior in scorpion Heterometrus fulvipes Brunner (Arachnida). Journal of Bioscience 19(1): 81-90.

Tikader, B.K. \& D.B. Bastawade (1983). Scorpions (Scorpionida: Arachnida). In: The Fauna of India, Vol. 3. Calcutta: Zoological Survey of India, $671 \mathrm{pp}$ 